Performance Test of Amorphous Silicon Modules in Different Climates - Year Four: Progress in Understanding Exposure History Stabilization Effects

\section{Preprint}

R. Rüther and A.A. Montenegro

LABSOLAR - Laboratório de Enegia Solar

J. del Cueto, S. Rummel, A. Anderberg, and B. Von Roedern

National Renewable Energy Laboratory

G. Tamizh-Mani

Arizona State University East

Presented at the 33rd IEEE Photovoltaic Specialists Conference San Diego, California

May 11-16, 2008
Conference Paper NREL/CP-520-42523

May 2008 


\section{NOTICE}

The submitted manuscript has been offered by an employee of the Midwest Research Institute (MRI), a contractor of the US Government under Contract No. DE-AC36-99G010337. Accordingly, the US Government and MRI retain a nonexclusive royalty-free license to publish or reproduce the published form of this contribution, or allow others to do so, for US Government purposes.

This report was prepared as an account of work sponsored by an agency of the United States government. Neither the United States government nor any agency thereof, nor any of their employees, makes any warranty, express or implied, or assumes any legal liability or responsibility for the accuracy, completeness, or usefulness of any information, apparatus, product, or process disclosed, or represents that its use would not infringe privately owned rights. Reference herein to any specific commercial product, process, or service by trade name, trademark, manufacturer, or otherwise does not necessarily constitute or imply its endorsement, recommendation, or favoring by the United States government or any agency thereof. The views and opinions of authors expressed herein do not necessarily state or reflect those of the United States government or any agency thereof.

Available electronically at http://www.osti.gov/bridge

Available for a processing fee to U.S. Department of Energy and its contractors, in paper, from:

U.S. Department of Energy

Office of Scientific and Technical Information

P.O. Box 62

Oak Ridge, TN 37831-0062

phone: 865.576 .8401

fax: 865.576 .5728

email: mailto:reports@adonis.osti.gov

Available for sale to the public, in paper, from:

U.S. Department of Commerce

National Technical Information Service

5285 Port Royal Road

Springfield, VA 22161

phone: 800.553 .6847

fax: 703.605.6900

email: orders@ntis.fedworld.gov

online ordering: http://www.ntis.gov/ordering.htm 


\title{
PERFORMANCE TEST OF AMORPHOUS SILICON MODULES IN DIFFERENT CLIMATES - YEAR FOUR: PROGRESS IN UNDERSTANDING EXPOSURE HISTORY STABILIZATION EFFECTS
}

\author{
R. Rüther ${ }^{1,2}$, J. del Cueto ${ }^{3}$, G. Tamizh-Mani ${ }^{4}$, A.A. Montenegro ${ }^{1}$, S. Rummel ${ }^{3}$, A. Anderberg ${ }^{3}$ \& B. von Roedern ${ }^{3}$ \\ ${ }^{1}$ LABSOLAR - Laboratório de Energia Solar \\ ${ }^{2}$ LabEEE - Laboratório de Eficiência Energética em Edificações, \\ Universidade Federal de Santa Catarina / UFSC, Caixa Postal 476, Florianopolis - SC, 88040-900 BRAZIL \\ Tel.: +55 $4837215174 \quad F A X:+554837217615$ Email: ruther@mbox1.ufsc.br \\ ${ }^{3}$ National Renewable Energy Laboratory, Thin-Film Partnership, 1617 Cole Boulevard, Golden CO 80401-3393, USA \\ Tel.: +1303 $3846480 \quad$ FAX: +1303 $3846790 \quad$ Email: Joseph_DelCueto@nrel.gov \\ ${ }^{4}$ Photovoltaic Testing Laboratory, Arizona State University East, 7349 East Unity Ave., Mesa AZ 85212 USA \\ Tel: +1 $4807271241 \quad$ FAX: +1 $4807271223 \quad$ Email: manit@asu.edu
}

\begin{abstract}
In a round robin outdoor exposure experiment carried out in three different climates, we have previously demonstrated that amorphous silicon (a-Si) PV modules reach higher stabilized performance levels in warmer climates. The four-year experiment involved three identical sets of thin-film a-Si modules from various manufacturers deployed outdoors simultaneously in three sites with distinct climates. Each PV module set spent a one-year period at each site before a final period at the original site where it was first deployed. The experiment aimed to determine the light-induced degradation and stabilization characteristics of a-Si regarding specific history of exposure, and to compare degradation rates in different climates. We propose that after the initial sharp degradation associated with the Stabler-Wronski effect (SWE) has passed, the subsequent stabilized performance levels attained will depend largely on light exposure and a characteristic temperature associated within a coherent time-scale. PV modules which were first deployed at the lowest-temperature site for one year, reaching a stabilized state, and were then further deployed at higher temperature sites for two more years, experienced considerable recovery in output parameters (Pmax and FF). However, when further deployed back at the original, lowest-temperature site, performance degraded back to the first year, original level.
\end{abstract}

\section{INTRODUCTION}

It is estimated that by 2010 the total annual production capacity for thin-film photovoltaic (PV) technologies worldwide will be more than 3.7 GWp [1]. There has been renewed interest in amorphous silicon (aSi) thin-film PV [2], spurred mostly by the current shortage of crystalline silicon (c-Si) modules on the market, due to the present favorable scenario for PV in many countries. Nearly $35 \%$ of the projected thin-film production capacity for 2010 is expected to be related to a-Si, amounting to some 1.3 GWp per year [1].

The reversible light-induced degradation of amorphous silicon (a-Si) thin-film solar cells, also known as the Staebler-Wronski effect (SWE [3]) results in a decrease in output performance after prolonged exposure to sunlight. The SWE leads to module performance reaching a stabilized state after the first year outdoors; most of this degradation can be reversed by thermal annealing at $150^{\circ} \mathrm{C}$ for 2 hours in the dark. It has been suggested that the stabilization of the SWE does not occur because an equilibrium between light-induced degradation and thermal or light-induced annealing is reached, but rather that it occurs because the degradation phenomenon itself is self-limiting, and that once enough degradation has been introduced (at a given minimum temperature), the degradation process fades away [4,5]. From this model, we derive the hypothesis that a-Si PV module long-term power output might depend not only on the operating conditions, but also on the temperature history of light exposure, and that a-Si devices operating at a year-round high temperature site, with higher minimum operating temperatures, will stabilize at higher performance levels than identical modules deployed at sites where minimum operating temperatures are lower, even if at both sites modules experience the same maximum operating temperatures. This aspect, associated with the negligible temperature coefficient of power of stabilized a-Si PV generators [6], gives this material a competitive edge for applications in warm climates [7-9].

In a four-year experiment designed to assess the performance of a-Si devices operating at three sites with different climates, we have previously shown that after the first year of outdoor exposure, modules deployed at the site with the highest minimum operating temperature experienced the highest stabilized output level [10]. 


\section{EXPERIMENTAL}

As previously reported [10-12] the experimental design involves three identical sets of seven multi-junction a-Si modules commercially available from five different manufacturers, which were simultaneously exposed outdoors in three sites with distinct climates, as described below, in a round robin exposure experiment. The fouryear experiment aims to determine the light-induced degradation and stabilization characteristics of multijunction a-Si PV modules with regards to geographic location- and climate-specific dependent effects, specific history of exposure effects, and to monitor and compare degradation rates in different climates. The three locations where the round-robin took place can have their climate conditions described as follows:

Site AZ: Mesa, Arizona - USA (Arizona State University Photovoltaic Testing Laboratory - PTL, Lat:: $33^{\circ} \mathrm{N}$ ); Climate: dry desert, with cool winters and hot summers;

Site CO: Golden, Colorado - USA (National Renewable Energy Laboratory - NREL, Lat.: $40^{\circ} \mathrm{N}$ ); Climate: dry continental, with cold winters and warm summers;

Site BR: Florianopolis, Santa Catarina - Brazil (Laboratorio de Energia Solar - LABSOLAR / UFSC, Lat.: $27^{\circ} \mathrm{S}$ ); Climate: moist maritime, with warm winters and hot summers.

An experimental procedure was designed, in which each PV module set would be deployed outdoors at one site for approximately 12 months, be shipped back to NREL for measurements under a SPIRE 240A simulator at Standard Testing Conditions (STC $=1000 \mathrm{~W} / \mathrm{m}^{2}$; AM 1.5 spectrum, operating cell temperature $25^{\circ} \mathrm{C}$ ); be sent to the next (second) site in the second year; and to the remaining site (third) in the third year, before being sent back to the original site where it was first deployed outdoors for a final deployment period in the fourth year. Every permutation of sites included STC measurements at NREL. During outdoor deployment, modules were individually connected to fixed resistive loads, in order to operate close to their maximum power point.

Initially, all samples from the three identical sets of double- and triple-junction, a-Si PV modules were measured for a baseline I-V trace at NREL at STC before shipment to each site for deployment outdoors.

In early 2001, within a one-week time window, each of the three sites started deploying one of the identical sets of modules outdoors, at fixed latitude tilt as per each site, facing toward the equator, and I-V characteristics under real operating conditions were measured on a monthly basis and normalized to STC.

\section{RESULTS AND DISCUSSION}

We follow up on results presented previously for the first, second, and third years of outdoor deployment [1012], adding our latest data in Figures $\mathbf{1}$ and 2.
Additionally, in Figure 3 we present real-time measurements of the fill factors obtained from I-V curves on single- tandem- and triple-junction modules deployed outdoors in Colorado, on the Performance and Energy Ratings Testbed (PERT), situated at the outdoor test facility at NREL, from June 2000 up to May 2006, comprising measurements in two irradiance ranges: 1000 \pm 25 and $250 \pm 12.5 \mathrm{~W} / \mathrm{m}^{2}$.
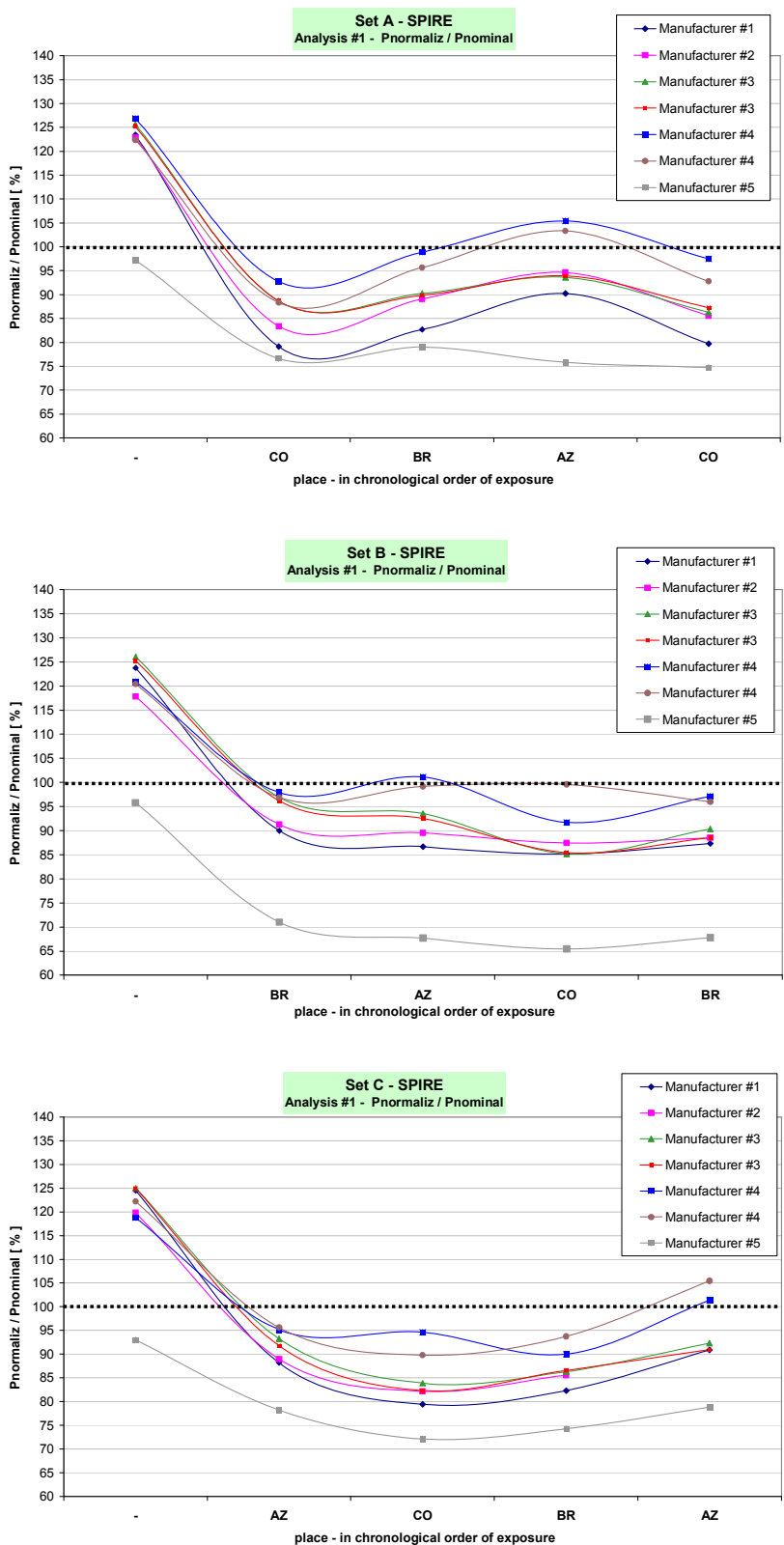

Figure 1: Evolution of the output power, normalized to nominal (nameplate) power, of the three sets of identical a-Si modules deployed outdoors in three different climates (the abscissa shows deployment sequence) over the four-year round-robin period. Set A (top pane) was first deployed in CO, Set B (middle pane) in BR, and Set $C$ (bottom pane) in $\mathbf{A Z}$. All measurements were carried out at NREL under a SPIRE 240A solar simulator at STC. 
Figure 1 shows the evolution of the output power at STC, normalized to nominal (nameplate) power, for the three sets of a-Si modules deployed outdoors over the four-year round-robin period. Set A (top pane) was first deployed in CO, Set B (mid pane) in BR, and Set C (bottom pane) in AZ. In all cases, PV modules which were on a stabilized state at one particular site, experienced either partial recovery or further decline in power output, depending on whether the next outdoor deployment period was finalized in a warmer or cooler weather at the time the modules were removed from the test rigs and sent to NREL for STC measurements.
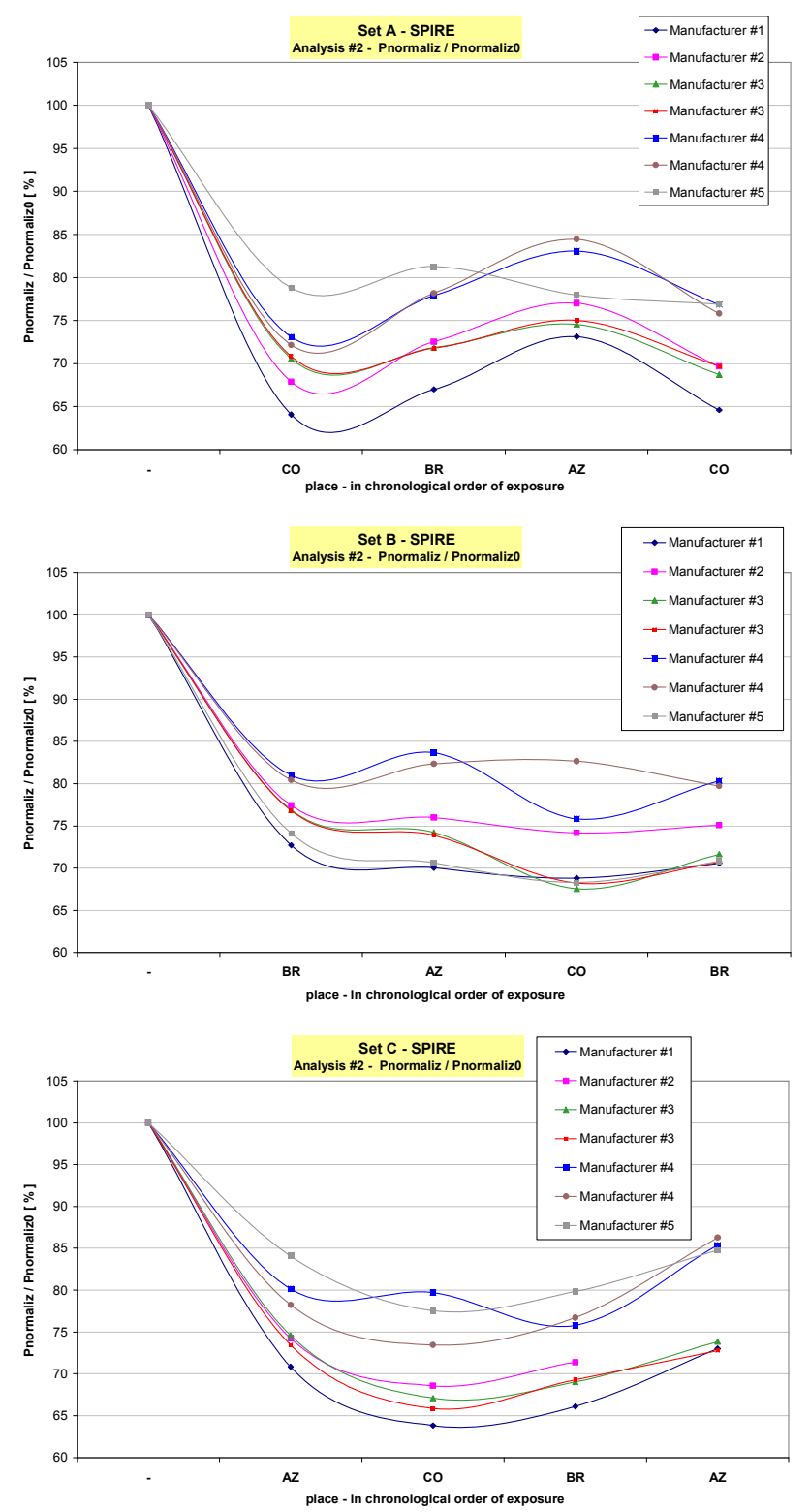

Figure 2: Evolution of the output power, normalized to original, unstabilized power, of the three sets of identical a-Si modules deployed outdoors in three different climates (the abscissa shows deployment sequence) over the four-year round-robin period. Set $A$ (top pane) was first deployed in CO, Set B (middle pane) in BR, and Set $\mathbf{C}$ (bottom pane) in $\mathbf{A Z}$. All measurements were carried out at NREL under a SPIRE 240A solar simulator at STC.
The recovery seen in all cases when modules were sent from $\mathbf{B R}$ to $\mathbf{A Z}$ (especially for Sets $A$ and $C$ ) can be traced back to higher temperatures (varying from 10 to $20^{\circ} \mathrm{C}$ ) at the $\mathbf{A Z}$ site during the season when modules were removed from the respective outdoor deployment rigs. Also noteworthy is the final decline experienced by Set $A$ when going back to its original site $\mathbf{C O}$.

Figure 1 also shows that most module manufacturers, except manufacturer \#5 in our experiment, underrate their product by 20 to $25 \%$ to account for the SWE, aiming at meeting their specification sheet performance at the stabilized state. For manufacturers \#1 to \#4 our results demonstrate that under a $+/-10 \%$ tolerance, module rating will meet specifications after four years of outdoor exposure in most cases. However, for module Set A, which was originally, and in the fourth year, deployed in the coolest site $\mathbf{C O}$, a number of samples reached the stabilized state at performance levels that would not meet specifications. Also, for Set C, when modules stabilized at site $\mathbf{A Z}$ were further deployed at site $\mathbf{C O}$, most of them reached a new stabilized state with performance levels below specifications. Modules from manufacturer \#5 showed the worst rating of all $P V$ modules measured; eventhough they would all meet a $+/$ $5 \%$ STC tolerance before outdoor exposure, none of the samples measured delivered their nameplate rating, not even before stabilization.

Figure 2 shows the same data presented in Figure 1, but normalized to original, unstabilized power, translating, therefore, the absolute amount of degradation in output experienced by all modules when deployed outdoors at the different site conditions. Here we see that modules from manufacturer \#5, which in Figure 1 presented the poorest rating, turned out to be the most stable of all manufacturers models in terms of StaeblerWronski degradation, especially in cooler climates. This figure also shows that most modules degraded from 20 to $30 \%$ during the first year of outdoor exposure, and that the spread in degradation levels among the different module types is relatively constant.

After the final round of outdoor deployment, we have submitted a selected sample of our PV modules to SPIRE measurements at different temperatures to determine their stabilized temperature coefficients. Table I shows the temperature coefficients, along with the adjusted square correlation coefficient of the fit (TmAve) for each power parameter fit. There were two temperatures measured on the module, front and back, as a result of temperature adjustments using a backside heater for varying temperature while the $\mathrm{PV}$ module was measured on the SPIRE. The power parameters temperature coefficients are defined as Tcoeff[Parm] $=\left(1 / \mathrm{Parm}\left(25^{\circ}\right)\right.$ * $\mathrm{dParm} / \mathrm{dTm}$, where $\mathrm{Tm}$ is average of front and back temperature measurements. These temperature coefficients are considerably lower than what is typically seen in these a-Si PV modules before stabilization, which are the temperature coefficients that manufacturers print on their products specification sheets. These lower temperature coefficients also confirm our previous field 
results [6], showing that at the system level, stabilized aSi PV arrays are virtually inert to (warmer than STC) operating temperatures.

Table I: Temperature coefficients of efficiency (Eff), open circuit voltage (Voc) and fill factor (FF) of a-Si modules after four years of outdoor deployment.

\begin{tabular}{llll}
\hline Manufacturer & Eff(\%) & Voc(\%) & $\mathrm{FF}(\%)$ \\
\hline \#2 (Tcoeff) & -0.105 & -0.316 & 0.120 \\
\#2 (adjusted R square) & 0.8760 & 0.9980 & 0.8793 \\
\#3 (Tcoeff) & -0.087 & -0.388 & 0.219 \\
\#3 (adjusted R square) & 0.6601 & 0.9962 & 0.9491 \\
\#3 (Tcoeff) & -0.079 & -0.363 & 0.186 \\
\#3 (adjusted R square) & 0.9252 & 0.9979 & 0.9825 \\
\#4 (Tcoeff) & -0.101 & -0.321 & 0.121 \\
\#4 (adjusted R square) & 0.9277 & 0.9981 & 0.9886 \\
\#4 (Tcoeff) & -0.053 & -0.294 & 0.128 \\
\#4 (adjusted R square) & 0.8150 & 0.9990 & 0.9878 \\
\hline
\end{tabular}

We propose that after the initial sharp degradation associated with the SWE in a-Si modules has passed, that subsequent stabilized performance levels attained will depend largely on light exposure and a characteristic temperature associated within a coherent time-scale. That stabilized level will exhibit either higher or lower values proportional to an exposure factor that scales as the product of the light intensity - i.e. exposure hours at fixed intensity - times the module temperature, and which reflects an accumulation history of this factor occurring for time intervals ranging 12-16 weeks prior. Figure 3 shows FF (\%) data plotted against time for single- (1-J), tandem(2-J) and triple-junction (3-J) modules. The FF data exhibit seasonal oscillations vs. time, with amplitudes of $\sim \pm 3 \%$ for all the modules in both high and low intensity ranges. The maxima of the fluctuations in FF occur about the end of August and the minima occur at the end of March. The fact that the amplitudes in FF fluctuations are all comparable in both high and low irradiance ranges, implies that these likely do not result via degradation in slope of the I-V characteristics at open and closed circuit, but instead are likely a result of variations in diode quality.

We support our claim that a-Si stabilization levels result from a mechanism reflecting the product of light exposure times temperature with data shown in Figure 4. This is a composite graph showing the cumulative integral of the irradiance times air temperature in the left pane, and the average of the product of the irradiance times air temperature on the right pane, both computed assuming four distinct summing intervals of time, 12, 16, 20 and 24 weeks prior, plotted vs. time. Note that the fluctuations shown plus peaks and troughs in both panes suggest a close correlation with that of the FF data in Figure 3 . The data on the left of Figure 4 depict sums of integrals over time and we suspect it more closely represents exposure than just the sums of the products on the right. The peaks and troughs are essentially shifted leftward by 4-6 weeks earlier for the integral data. Note also that the effect of longer summing time (weeks) intervals computed result in extrema that shift toward later times. We also point out that if instead of these products of irradiance times air temperature, one were just to plot the cumulative sums of irradiance integral $\left(\mathrm{kWhr} / \mathrm{m}^{2}\right)$, those sums do not exhibit similar structure - periodic fluctuations or amplitudes because irradiance sums over prior 12-24 weeks actually exhibit larger variations due to weather. By comparing the extrema in both Figures 3 and 4, we then propose that after the initial SWE onset has passed, that a-Si stabilization behaves as if it has a memory of its light and temperature exposure for a time span of 12-16 weeks.
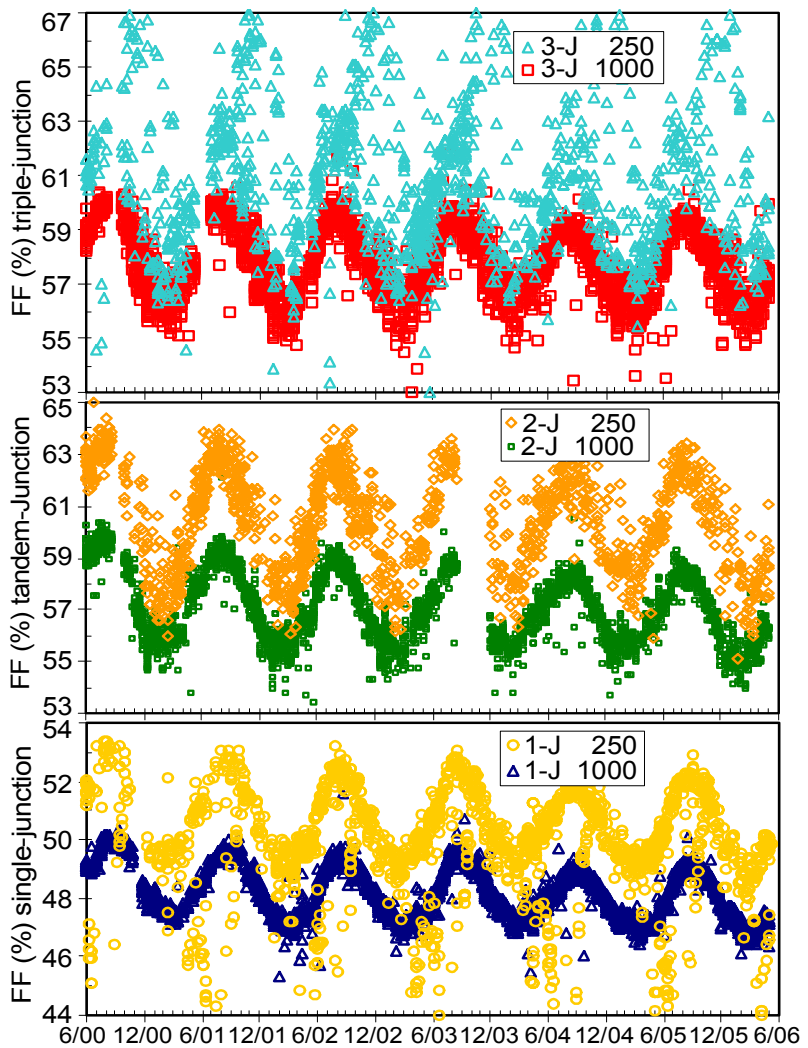

Figure 3: FF data for single- (1-J), tandem- (2-J) and triplejunction (3-J) a-Si modules, depicted, respectively, in bottom, mid and top panes, plotted vs. date, in two irradiance ranges: 1000 and $250 \mathrm{~W} / \mathrm{m}^{2}$.

\section{CONCLUSIONS}

We have shown that after the initial sharp degradation associated with the SWE has passed, the subsequent stabilized performance levels attained will depend largely on light exposure and a characteristic temperature associated within a coherent time-scale. PV modules which were first deployed at the lowesttemperature site for one year, reaching a stabilized state, and were then further deployed at higher temperature sites for two more years, experienced considerable recovery in output parameters. However, when further deployed back at the original, lowest-temperature site, performance degraded back to the first year, original level. We have presented results that corroborate our original hypothesis that a site where PV modules experience higher operating temperatures year-round, will lead to higher stabilized performance levels. 


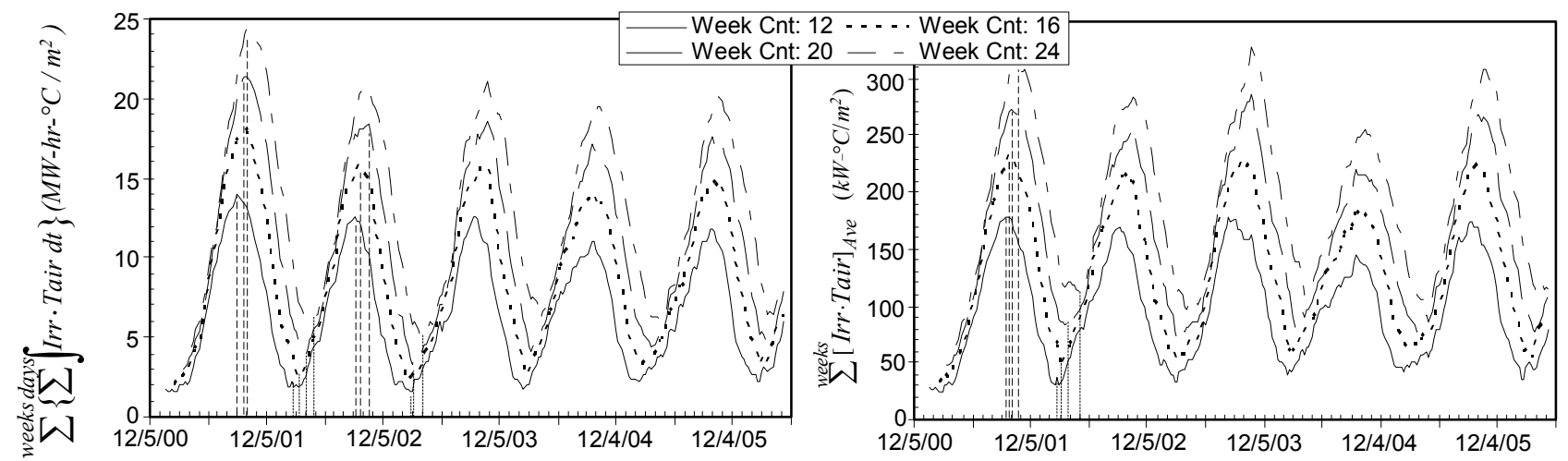

Figure 4: Cumulative sums over prior 12, 16, 20 and 24 weeks of: the integral of air temperature times irradiance with time in left pane, and product of air temperature times irradiance on the right, for Golden, $\mathrm{CO}$, plotted vs. date.

\section{REFERENCES}

[1] H.S.Ullal \& B. von Roedern, „Thin-Film CIGS and CdTe Photovoltaic Technologies: Commercialization, Critical Issues, and Applications, $22^{\text {nd }}$ European PV Solar Energy Conference, Milan - Italy, 2007, pp. 1-4.

[2] K.Zweibel, B. von Roedern \& H. Ullal, "Finally: Thinfilm PV!", Photon International, October, 2004, pp.48-54.

[3] D.L.Staebler \& C.R.Wronski, "Reversible Conductivity Changes in Discharge-Produced Amorphous Si", Appl. Phys. Lett. 31, 1977, pp. 292-294.

[4] B. von Roedern \& B. Kroposki, "Can the StaeblerWronski Effect Account for the Long-Term Performance of a-Si PV Arrays?", $14^{\text {th }}$ NREL/SNL PV Program Review Meeting - AIP Conf. Proc, AIP, Lakewood, 1996, pp. 313316.

[5] J.del Cueto \& B.von Roedern, "Temperature-Induced Changes in the Performance of Amorphous Silicon MultiJunction Modules in Controlled Light-Soaking", Prog. Photovolt: Res. Appl. 7, 1999, pp. 101-112.

[6] R.Rüther, H.G.Beyer, A.A.Montenegro, M.M.Dacoregio. I.T. Salamoni \& P.Knob, "Performance Results of the First Grid-Connected, Thin-Film PV Installation in Brazil: Temperature Behaviour and Performance Ratios over Six Years of Continuous Operation", $19^{\text {th }}$ European Photovoltaic Solar Energy Conference, Paris - France, 2004, pp. 1487-1490.

[7] R.Rüther, P.Knob, H.G.Beyer, M.M.Dacoregio \& A.A.Montenegro, "High Performance Ratios of a DoubleJunction a-Si BIPV Grid-Connected Installation After Five Years of Continuous Operation in Brazil", $3^{\text {rd }}$ World Conference on PV Energy Conversion, WCPEC3, Osaka - Japan, 2003, pp. 3091-3094.

[8] R.Rüther, "Demonstrating the Superior Performance of Thin-Film, Amorphous Silicon for Building-Integrated PV Systems in Warm Climates", International Solar Energy
Society's 1999 Solar World Congress, ISES, Jerusalem, 1999, pp. 221-224.

[9] R. Rüther \& J. Livingstone, "Seasonal variations in amorphous silicon solar module outputs and thin film characteristics", Sol. Energy Mater. and Solar Cells 36, 1994, pp. 29-41.

[10] R.Rüther, G.Mani, J.del Cueto, J.Adelstein, A.Montenegro \& B.von Roedern, "Performance Test of Amorphous Silicon Modules in Different Climates: Higher Minimum Operating Temperatures Lead to Higher Performance Levels", $3^{\text {rd }}$ World Conference on PV Energy Conversion, WCPEC3, Osaka - Japan, 2003, pp. 501504.

[11] R.Rüther, G.Mani, J.del Cueto, J.Adelstein, A.Montenegro \& B.von Roedern, "Performance Test of Amorphous Silicon Modules in Different Climates - Year Two: Higher Minimum Operating Temperatures Lead to Higher Performance Levels", $19^{\text {th }}$ European PV Solar Energy Conference, Paris - France, 2004, pp. 1617-1620.

[12] R.Rüther, G.Mani, J.del Cueto, J.Adelstein, M.Dacoregio \& B.von Roedern, "Performance Test of Amorphous Silicon Modules in Different Climates - Year Three: Higher Minimum Operating Temperatures Lead to Higher Performance Levels", $31^{\text {st }}$ IEEE Photovoltaic Specialists Conference, Orlando - USA, 2005, pp. 1-4. 
PLEASE DO NOT RETURN YOUR FORM TO THE ABOVE ORGANIZATION.
1. REPORT DATE (DD-MM-YYYY) May 2008

\section{REPORT TYPE \\ Conference Paper}

4. TITLE AND SUBTITLE

Performance Test of Amorphous Silicon Modules in Different

Climates - Year Four: Progress in Understanding Exposure History

Stabilization Effects

6. AUTHOR(S)

R. Rüther, J. del Cueto, G. Tamizh-Mani, A.A. Montenegro;

S. Rummel, A. Anderberg, and B. von Roedern
3. DATES COVERED (From - To)

11-16 May 2008

5a. CONTRACT NUMBER

DE-AC36-99-GO10337

5b. GRANT NUMBER

5c. PROGRAM ELEMENT NUMBER

5d. PROJECT NUMBER

NREL/CP-520-42523

5e. TASK NUMBER

PVB77101

5f. WORK UNIT NUMBER
7. PERFORMING ORGANIZATION NAME(S) AND ADDRESS(ES)

National Renewable Energy Laboratory

1617 Cole Blvd.

Golden, CO 80401-3393

9. SPONSORING/MONITORING AGENCY NAME(S) AND ADDRESS(ES)
8. PERFORMING ORGANIZATION REPORT NUMBER

NREL/CP-520-42523

10. SPONSOR/MONITOR'S ACRONYM(S) NREL

11. SPONSORING/MONITORING AGENCY REPORT NUMBER

12. DISTRIBUTION AVAILABILITY STATEMENT

National Technical Information Service

U.S. Department of Commerce

5285 Port Royal Road

Springfield, VA 22161

13. SUPPLEMENTARY NOTES

\section{ABSTRACT (Maximum 200 Words)}

In a round robin outdoor exposure experiment carried out in three different climates, we have previously demonstrated that amorphous silicon (a-Si) PV modules reach higher stabilized performance levels in warmer climates. The four-year experiment involved three identical sets of thin-film a-Si modules from various manufacturers deployed outdoors simultaneously in three sites with distinct climates. Each PV module set spent a one-year period at each site before a final period at the original site where it was first deployed. The experiment aimed to determine the light-induced degradation and stabilization characteristics of a-Si regarding specific history of exposure, and to compare degradation rates in different climates. We propose that after the initial sharp degradation associated with the Stabler-Wronski effect (SWE) has passed, the subsequent stabilized performance levels attained will depend largely on light exposure and a characteristic temperature associated within a coherent time-scale. PV modules which were first deployed at the lowest-temperature site for one year, reaching a stabilized state, and were then further deployed at higher temperature sites for two more years, experienced considerable recovery in output parameters (Pmax and FF). However, when further deployed back at the original, lowest-temperature site, performance degraded back to the first year, original level.

\section{SUBJECT TERMS}

PV: amorphous silicon; modules; thin film; Staebler-Wronski effect; light-induced degradation; coefficients of efficiency; open-circuit voltage; fill factor

\begin{tabular}{|l|l|l|l|l|}
\hline \multicolumn{3}{|l|}{ 16. SECURITY CLASSIFICATION OF: } & $\begin{array}{c}\text { 17. LIMITATION } \\
\text { OF ABSTRACT }\end{array}$ & $\begin{array}{c}\text { 18. NUMBER } \\
\text { OF PAGES }\end{array}$ \\
\hline $\begin{array}{l}\text { a. REPORT } \\
\text { Unclassified }\end{array}$ & $\begin{array}{c}\text { b. ABSTRACT } \\
\text { Unclassified }\end{array}$ & $\begin{array}{c}\text { c. THIS PAGE } \\
\text { Unclassified }\end{array}$ & $\begin{array}{c}\text { UL } \\
\end{array}$ &
\end{tabular}

19a. NAME OF RESPONSIBLE PERSON

19b. TELEPHONE NUMBER (Include area code) 